\section{Response to 'Antinuclear antibodies by indirect immunofluorescence and solid phase assays' by Bossuyt et al}

We would like to thank Dr Bossuyt and colleagues ${ }^{1}$ for their comments on our article on variability in testing for antinuclear antibodies (ANA). ${ }^{2}$ This letter, along with previous correspondence, ${ }^{3-9}$ highlights the many issues about ANA testing and the results obtained with different assay platforms. We agree that a combination of different assays can be a valuable approach to assess more completely the serological profile of patients with autoantibody-associated rheumatic disease (AARD). We would note, however, that, just as indirect immunofluorescence assays (IIF) can differ in performance characteristics, so too can solid phase assays (SPA). For SPA, differences can result from the composition of the antigens on the solid phase and the use of mixtures of purified proteins in contrast to a cell extract. It is important, therefore, that studies with SPA indicate antigens present as Bossuyt et al have done in their letter.

In our study that was published in Annals of Rheumatic Diseases, we focused on systemic lupus erythematosus (SLE), seeking to understand the high frequency of ANA negativity observed in screening of patients for clinical trials for new agents. ${ }^{2}$ We have also been interested in the proposed use of ANA positivity as a criterion for the classification of patients with SLE. ${ }^{10-12}$ Since the array of ANA expressed in SLE differs from that of other AARD, testing of a variety of IIF and SPA kits may be necessary to find a combination most applicable to this disease. ANA expression has been viewed as almost invariable in SLE although this conclusion is based on the assays used for these determinations and therefore may be worth revisiting. Future studies with SLE and other AARD will be necessary to define better serological findings over the course of disease, including the effects of therapy on various ANA.

\section{David S Pisetsky, ${ }^{1}$ Diane M Spencer, ${ }^{1}$ Peter E Lipsky, ${ }^{2}$ Brad H Rovin ${ }^{3}$ ${ }^{1}$ Department of Medicine and Immunology, Duke University Medical Center, Durham, North Carolina, USA \\ ${ }^{2}$ RILITE Research Institute, Charlottesville, Virginia, USA \\ ${ }^{3}$ Division of Nephrology, Department of Internal Medicine, Ohio State University Wexner Medical Center, Columbus, Ohio, USA}

Correspondence to Dr David S Pisetsky, Department of Medicine and Immunology, Duke University Medical Center, Durham, NC 27705, USA; david.pisetsky@duke.edu

Handling editor Josef S Smolen

Competing interests None declared.
Patient consent for publication Not required.

Provenance and peer review Commissioned; internally peer reviewed.

(c) Author(s) (or their employer(s)) 2020. No commercial re-use. See rights and permissions. Published by BMJ.

DSP and DMS contributed equally.

\section{Check for updates}

To cite Pisetsky DS, Spencer DM, Lipsky PE, et al. Ann Rheum Dis 2020;79:e66.

Received 12 April 2019

Accepted 12 April 2019

Published Online First 10 May 2019

\section{(S) Linked}

http://dx.doi.org/10.1136/annrheumdis-2019-215443

Ann Rheum Dis 2020:79:e66. doi:10.1136/annrheumdis-2019-215479

\section{REFERENCES}

1 Bossuyt $\mathrm{X}$, DeLanghe $\mathrm{E}$, Belmondo T, et al. Antinuclear antibodies by indirect immunofluorescence and solid phase assays. Ann Rhem Dis 2020;79:e65.

2 Pisetsky DS, Spencer DM, Lipsky PE, et al. Assay variation in the detection of antinuclear antibodies in the sera of patients with established SLE. Ann Rheum Dis 2018;77:911-3.

3 Infantino M, Manfredi M, Soda P, et al. ANA testing in 'real life'. Ann Rheum Dis 2020;79:e3.

4 Mahler M. Lack of standardisation of ANA and implications for drug development and precision medicine. Ann Rheum Dis 2019;78:e33.

5 Meroni PL, Chan EK, Damoiseaux J, et al. Unending story of the indirect immunofluorescence assay on HEp-2 cells: old problems and new solutions? Ann Rheum Dis 2019:78:e46.

6 Pacheco Y, Monsalve DM, Acosta-Ampudia Y, et al. Antinuclear autoantibodies: discordance among four different assays. Ann Rheum Dis 2020;79:e6.

7 Pregnolato F, Borghi MO, Meroni PL, et al. Pitfalls of antinuclear antibody detection in systemic lupus erythematosus: the positive experience of a national multicentre study. Ann Rheum Dis 2019;78:e50.

8 Van Hoovels L, Schouwers S, Van den Bremt S, et al. Variation in antinuclear antibody detection by automated indirect immunofluorescence analysis. Ann Rheum Dis 2019;78:e48.

9 Willems P, De Langhe E, Westhovens R, et al. Antinuclear antibody as entry criterion for classification of systemic lupus erythematosus: pitfalls and opportunities. Ann Rheum Dis 2019;78:e76.

10 Leuchten N, Hoyer A, Brinks R, et al. Performance of antinuclear antibodies for classifying systemic lupus erythematosus: a systematic literature review and metaregression of diagnostic data. Arthritis Care Res 2018;70:428-38.

11 Pisetsky DS, Lipsky PE. Role of antinuclear antibody determinations in classification criteria for systemic lupus erythematosus: Comment on the article by Leuchten et al. Arthritis Care Res 2018. doi:10.1002/acr.23559. [Epub ahead of print: 25 Mar 2018].

12 Tedeschi SK, Johnson SR, Boumpas D, et al. Developing and refining new candidate criteria for systemic lupus erythematosus classification: an international collaboration. Arthritis Care Res 2018;70:571-81. 